\title{
Vertical Eddy Diffusion Coefficient in Lake Zürich
}

\author{
By YUAN-HuI LI \\ Swiss Federal Institute for Water Resources and Water Pollution Control (EAWAG) \\ at Swiss Federal Institute of Technology (ETH)
}

\section{ABSTRACT}

The vertical eddy diffusion coefficient in Lake Zürich is a strong function of both depth and season. In the deep lake, the annual oxygen consumptions by the oxidation of organic carbon is balanced out by the equal amount of oxygen supply from above by diffusion.

Schmidt [2], Mortimer [1] and others have estimated the vertical eddy diffusion coefficient $D(z, t)$ of many lakes by the equation:

$$
\begin{aligned}
& F(z, t)=\int_{z}^{z_{1}}(\partial T(z, t) / \partial t)_{z} d z \\
& =-D(z, t) \cdot(\partial T(z, t) / \partial z)_{t}
\end{aligned}
$$

where $F(z, t)=$ the total heat diffused through a unit horizontal area per unit time at depth $z$ and time $t$.

$\partial T / \partial z$ and $\partial T / \partial t=$ the partial differentials or the observed slopes of temperature plotted against depth and time respectively. $z_{1}=$ the depth where $\partial T / \partial t=0$, or bottom depth.

Equation (1) is applicable only under the conditions that: a) there is no vertical advection of lake water, b) the net horizontal heat transport is negligible i.e., the horizontal advection and/or horizontal temperature gradient are negligibly small and c) the heat exchange between water and bottom sediments is small. Fortunately Lake $Z$ ürich satisfies the above conditions (more or less).

Zimmermann [3] summarized the average monthly temperatures of Lake Zürich as a function of depth down to the bottom at one station over a period of 10 years (1948-57, Fig. 1). The advantage of using the average temperature of several years is that any random factors (either climatic or observational) have been smoothed out, so the reading of $\partial T / \partial t$ and $\partial T / \partial z$ for each observational point from the smoothed curves (in Fig. 1 and monthly $T-z$ plots) becomes easier. $D(z, t)$ calculated from April to December at a depth above $60 \mathrm{~m}$ by using Zimmermann's data are given in Table 1 and plotted in Figure 2. At a depth below $60 \mathrm{~m}$, the $\partial T / \partial t$ and $\partial T / \partial z$ terms become so small and the uncertainty in $D(z, t)$ so big, that no attempt is made to calculate $D$ 
Table 1. The vertical eddy diffusion coefficients of Lake Zürich $D\left(\mathrm{~cm}^{2} / \mathrm{sec}\right)$.

Depth April May June July August Sept. Oct. Nov. Depth Also for Feb. (m) and (m) (Jan. and March) Dec.

\begin{tabular}{lllllllllll}
\hline 5 & 0.71 & 0.35 & 0.17 & 0.110 & 0.18 & - & - & - & 60 & 9.78 \\
7.5 & 0.88 & 0.21 & 0.065 & 0.054 & 0.052 & - & - & - & 70 & 4.20 \\
10 & 1.06 & 0.14 & 0.064 & 0.041 & 0.026 & 0.020 & - & - & 80 & 3.34 \\
12.5 & 1.35 & 0.18 & 0.073 & 0.039 & 0.035 & 0.020 & - & - & 90 & 2.31 \\
15 & $\mathbf{1 . 5 1}$ & 0.28 & 0.090 & 0.082 & 0.050 & 0.023 & - & - & 100 & 1.21 \\
17.5 & $\mathbf{1 . 6 6}$ & 0.37 & 0.22 & 0.110 & 0.065 & 0.046 & - & - & 110 & 0.95 \\
20 & 1.86 & 0.61 & 0.29 & 0.14 & 0.11 & 0.072 & 0.074 & - & 120 & 0.68 \\
25 & 2.23 & 0.81 & 0.37 & 0.18 & 0.18 & 0.108 & 0.11 & 0.51 & & \\
30 & 2.70 & 0.90 & 0.44 & 0.27 & 0.20 & 0.17 & 0.12 & 0.64 & & \\
40 & 4.02 & 1.00 & 0.48 & 0.31 & 0.25 & 0.18 & 0.16 & 0.68 & & \\
50 & 4.30 & 1.07 & 0.45 & 0.33 & 0.28 & 0.17 & 0.18 & 0.59 & & \\
60 & $\mathbf{3 . 7 5}$ & 1.35 & 0.43 & 0.34 & 0.28 & - & - & 0.62 & & \\
& & & & & & & & & &
\end{tabular}

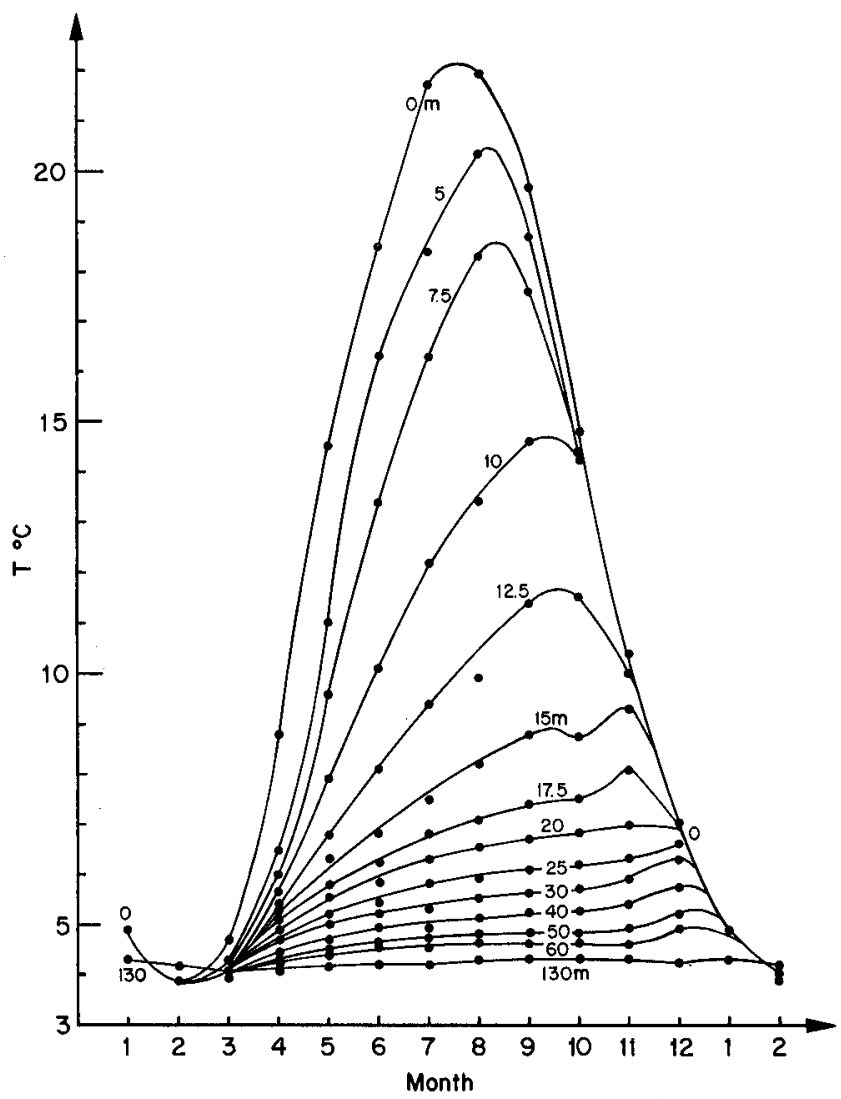

Fig. 1. The monthly variation of temperature in Lake Zürich for the different depths. 
below $60 \mathrm{~m}$ from the temperature data. Also at shallow depths where the disturbance of water body is strong, $D$ was not calculated. The uncertainty of $D$ above $40 \mathrm{~m}$ is about $10 \%$, and below $40 \mathrm{~m}$, about $20 \%$ between April and June and $30 \%$ or more between July and October. The uncertainty of $D$ can be largely attributed to the uncertainty of $\partial T / \partial t$ at a depth below $60 \mathrm{~m}$, therefore the accurate measurement of temperatures at greater depths is very critical $\left.{ }^{1}\right)$. As shown in Figure 2, the $D$ minimum (May to September) corresponds nicely to the thermocline. $D$ also changes with

1) Unfortunately, most of recent continuous-temperature-profile measurements by thermocouple devices were usually calibrated at the surface of a lake so that the monthly temperature measurements at depth fluctuate even by as much as $0.4^{\circ} \mathrm{C}$, which can hardly be explained by a sudden climatic change. So my personal plea is that the continuous temperature profile should be calibrated against the temperature at depth by using reversible thermometers as 'old time' limnologists used to do.

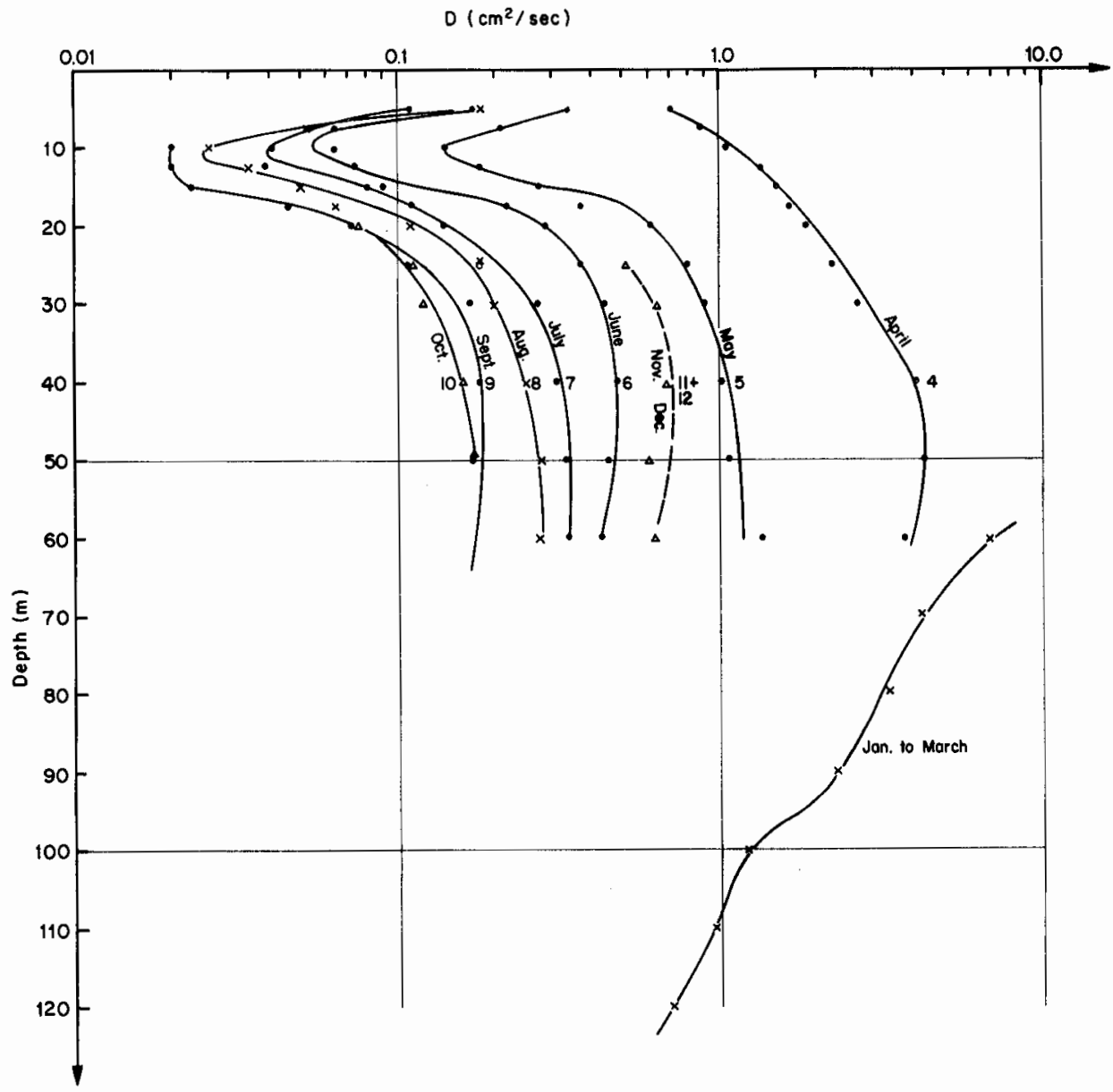

Fig. 2. The vertical eddy diffusion coefficients as a function of both depth and month. 
Table 2. Oxygen fluxes at depths 10,20 and $60 \mathrm{~m}$ and the net gain and loss of oxygen in the water columns.

\begin{tabular}{|c|c|c|c|c|c|}
\hline & $(\mathrm{mg} \mathrm{C}$ & nonth) & & & \\
\hline & $10 \mathrm{~m}$ & $20 \mathrm{~m}$ & $60 \mathrm{~m}$ & $(10-20)$ & $(20-60)$ \\
\hline April & 3.05 & 2.76 & 3.02 & 0.29 & -0.26 \\
\hline May & 1.40 & 0.82 & 1.06 & 0.57 & -0.23 \\
\hline June & 0.84 & 0.13 & 0.51 & 0.71 & -0.38 \\
\hline July & 0.70 & -0.20 & 0.23 & 0.90 & -0.43 \\
\hline August & 0.52 & -0.23 & 0.23 & 0.75 & -0.45 \\
\hline September & 0.55 & -0.17 & 0.20 & 0.72 & -0.37 \\
\hline October & 0.56 & -0.23 & 0.18 & 0.79 & -0.41 \\
\hline November & & & 0.45 & & \\
\hline December & & & 0.35 & & \\
\hline January & & & $\mathbf{1 1 . 9 1}$ & & \\
\hline February & & & 13.44 & & \\
\hline March & & & 7.61 & & \\
\hline Total & & & 39.19 & & \\
\hline
\end{tabular}

depth by almost one order of magnitude and decreases from April to October more than one order of magnitude i.e., the lake as a whole becomes increasingly stagnant till October. Certainly in any calculation dealing with material transport by diffusion in the lake, one can not neglect the fact that $\mathrm{D}$ is a strong function of both depth and season.

ZIMMERMANN [3] also summarized the average monthly oxygen concentration $\left[\mathrm{O}_{2}\right]$ of Lake $Z$ ürich over the same 10 year-period as plotted in Figure 3 . The average rate of decrease of oxygen concentration during the summer stratification period, $J_{z}$, and the rate of increase of oxygen concentration in February, $\left(\partial\left[\mathrm{O}_{2}\right] / \partial t\right)_{z}$, are also plotted in Figure $4\left(J_{z}\right.$ and $\left(\partial\left[\mathrm{O}_{2}\right] / \partial t\right)_{z}$ were both directly read from Fig. 3). Both $J_{z}$ and $\left(\partial\left[\mathrm{O}_{2}\right] / \partial t\right)_{z}$ represent a net effect of a) the rate of oxidation of organic carbon by biological processes and b) the supply rate of oxygen by diffusion from above. Fortunately, the latter is much smaller than the former at a depth below $60 \mathrm{~m}$ during the summer stratification period as will be shown later. Therefore, $J_{z}$ at a depth below $60 \mathrm{~m}$ is very close to the true oxidation rate of organic carbon. Since the temperature at any depth below $60 \mathrm{~m}$ changes annually by no more than $0.5{ }^{\circ} \mathrm{C}$ which exerts a negligible influence (for our purpose) on the rate of biological processes. Thus, one may assume the same value for $J_{z}$ holds in winter as well as in summer. As a consequence, $J_{z}+\left(\partial\left[\mathrm{O}_{2}\right] / \partial t\right)_{z}$ represents approximately a true increasing rate of oxygen supply in winter. By re-formulating equation (1) for oxygen, one can calculate $D$ in February at a depth below $60 \mathrm{~m}$ by the equation:

$$
\text { Vertical Flux of } \mathrm{O}_{2}=\int_{z}^{z_{1}}\left(J+\partial\left[\mathrm{O}_{2}\right] / \partial t\right)_{z} d z=-D\left(\partial\left[\mathrm{O}_{2}\right] / \partial_{z}\right)_{t} \text {. }
$$

All pertinent data are given in Figure 4 and the results in Figure 2 and Table 1. $\mathrm{D}$ at a depth below $60 \mathrm{~m}$ decreases exponentially with depth and shows a change of 


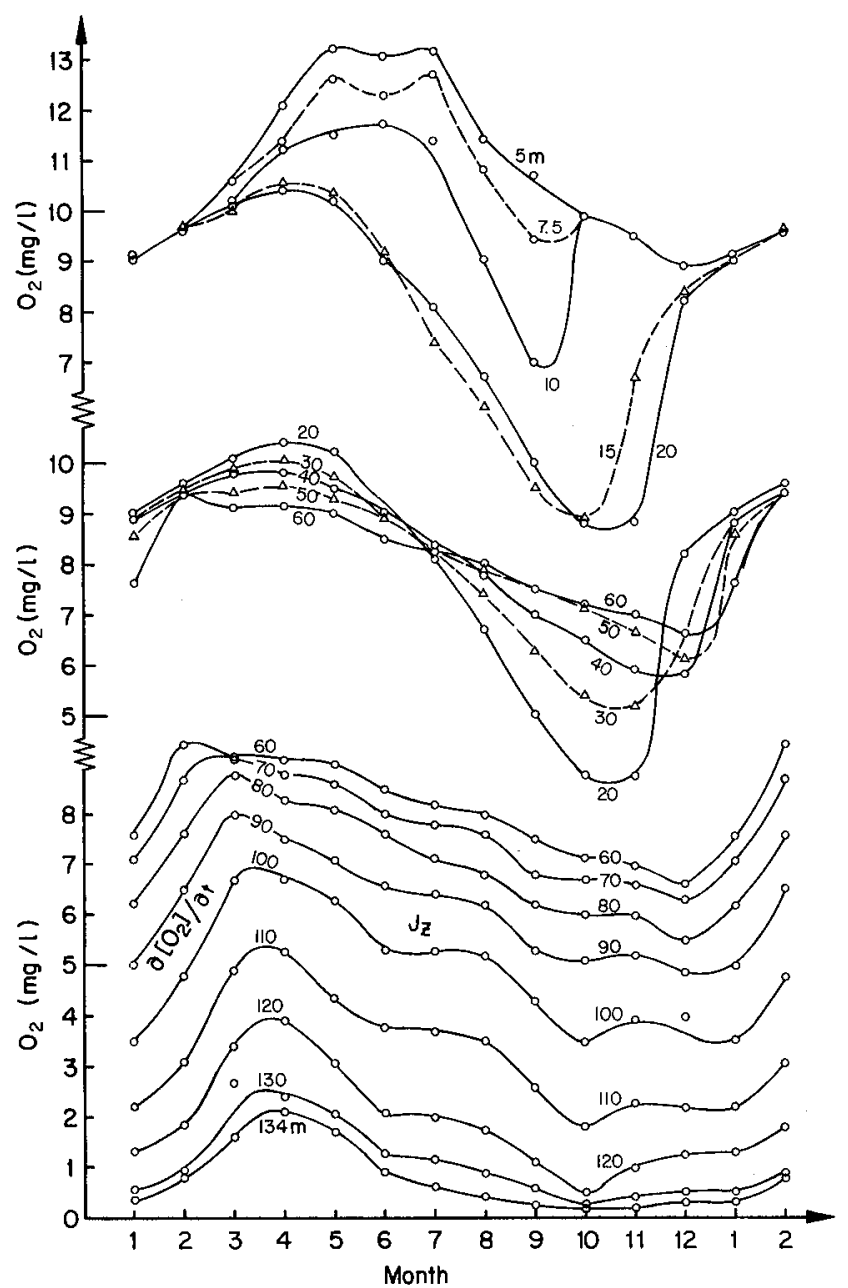

Fig. 3. The monthly variation of oxygen concentration in Lake Zürich for the different depths.

slope at a depth of $100 \mathrm{~m}$. Above $60 \mathrm{~m}$, the water is well mixed in regard to oxygen concentration (Fig. 4).

In order to study the oxygen budget of Lake Zürich, the monthly oxygen flux by diffusion at $10 \mathrm{~m}$ and $20 \mathrm{~m}$ depths during the summer stratification period and at $60 \mathrm{~m}$ depth for a whole year were calculated by using the obtained $D(z, t)$ (Table 1 ) and the observed $\left(\partial\left[\mathrm{O}_{2}\right] / \partial_{z}\right)_{t}$. The results are given in Table 2 along with the monthly net gain or loss of oxygen from water columns (i.e., 10 to $20 \mathrm{~m}$ and 20 to $60 \mathrm{~m}$ intervals). Adding up the values of the $4^{\text {th }}$ column of Table 2, the total annual flux of oxygen from above at $60 \mathrm{~m}$ depth is about $39.19 \mathrm{mg} / \mathrm{cm}^{2} \cdot$ year. On the other hand, the total annual consumption of oxygen by oxidation of organic carbon in the water column below $60 \mathrm{~m}$ is $39.24 \mathrm{mg} / \mathrm{cm}^{2}$. year, obtained by integrating $J_{z}$ in the water column below $60 \mathrm{~m}$ and multiplying by 12, in good agreement with the above diffu- 


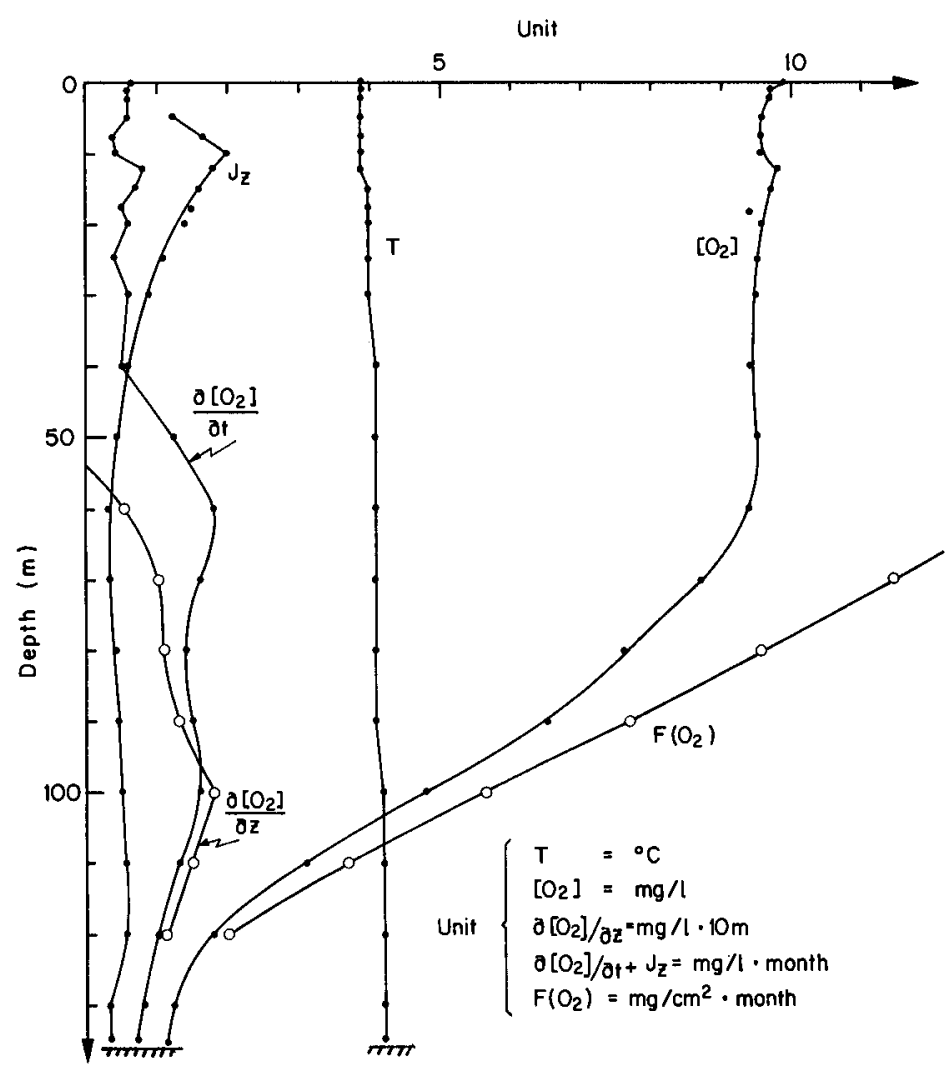

Fig. 4. $\left[\mathrm{O}_{2}\right], \partial\left[\mathrm{O}_{2}\right] / \partial z, \partial\left[\mathrm{O}_{2}\right] / \partial t, \mathrm{~F}\left(\mathrm{O}_{2}\right)$ in February and $J z$ in summer stratification period as a function of depth.

sion calculation (the near exact agreement is fortuitous). About $8 \%$ of annual oxygen flux to the water column below $60 \mathrm{~m}$ was transported during the summer stratification period i.e., from May to October, and $92 \%$ in the rest of the year (Table 2). If this $8 \%$ of annual oxygen flux is evenly distributed in the water column below $60 \mathrm{~m}$, one could expect a rate of increase of $\left[\mathrm{O}_{2}\right]$ of about $0.043 \mathrm{mg} \mathrm{O}_{2} / 1 \cdot$ month which is only about $10 \%$ of the apparent oxidation rate of organic carbon, $J_{z}$, in the same water column. ( $J_{z}$ ranges from 0.32 to $0.56 \mathrm{mg} / 1 \cdot \mathrm{month}$ and in average 0.44 $\mathrm{mg} / 1 \cdot$ month.) In a water column between $20 \mathrm{~m}$ and $60 \mathrm{~m}$ oxygen is transported out at both ends by diffusion throughout the whole year, thereby the water column loses on the average about $0.072 \mathrm{mg} \mathrm{O} / 1 \cdot$ month, which is again relatively small as compared with $J_{z}$ (average $0.7 \mathrm{mg} \mathrm{O}_{2} / 1 \cdot$ month) in the same water column. Meanwhile, in the water column between $10 \mathrm{~m}$ and $20 \mathrm{~m}$, the average gain of oxygen by diffusion during the summer stratification period is about $0.74 \mathrm{mg} \mathrm{O}_{2} / 1 \cdot$ month which is no longer a negligible amount as compared with $J_{z}$ (average $1.6 \mathrm{mg} / 1 \cdot$ month, ranging from 1.4 to $2.0 \mathrm{mg} / \mathrm{l} \cdot \mathrm{month}$ ) in the same water column. The true average oxidation rate of organic carbon in the water column between $10 \mathrm{~m}$ and $20 \mathrm{~m}$ then should be $1.6+0.74=2.34 \mathrm{mg} \mathrm{O} / 1 \cdot$ month. 


\section{Summary}

1. The vertical eddy diffusion coefficient of Lake Zürich is a strong function of both depth and season. 2. The oxygen budget in the deep lake can be explained by the oxygen supply from above by diffusion and the oxidation of organic carbon by biological processes. 3. During the summer stratification period, the oxygen transport by diffusion has only a minor effect on the oxygen concentration in the water column below $20 \mathrm{~m}$, but in the zone of the oxygen minimum (10 to $20 \mathrm{~m}$ ), the oxygen transport by diffusion becomes important as compared to the magnitude of oxygen consumption by biological processes.

\section{ZUSAMMENFASSUNG}

1. Der vertikale Austauschkoeffizient im Zürichsee hängt streng von der Tiefe und der Jahreszeit ab. 2. Der Sauerstoffhaushalt in der Seetiefe lässt sich durch austauschbedingte Zufuhr von oben und durch die Oxidation organischen Kohlenstoffs durch biologische Prozesse erklären. 3. Während der sommerlichen Stagnationsperiode wirkt sich der Sauerstofftransport durch Austausch nur sehr schwach auf die Sauerstoffkonzentration in der Wassertiefe unterhalb $20 \mathrm{~m}$ Tiefe aus. In der Zone des metalimnischen Sauerstoffminimums (10 bis $20 \mathrm{~m})$ hingegen erlangt der Sauerstofftransport durch Austausch gegenüber dem biogenen Sauerstoffverbrauch eine grosse Bedeutung.

\section{RÉSUMÉ}

1. Le facteur de diffusion verticale dans le lac de Zurich dépend étroitement de la profondeur et la saison. 2. La concentration actuelle en oxygène de la couche profonde est déterminée par l'apport de la surface lors de la diffusion ct par l'oxydation du carbone organique lors des processus biologiques décomposants. 3. Pendant la période de stratification estivale l'oxygène apporté lors de la diffusion n'a qu'une très faible influence sur la concentration d'oxygène dans les couches en-dessous de $20 \mathrm{~m}$ de profondeur. Dans la zone du metalimnion où l'oxygène est réduit à son minimum $(10$ à $20 \mathrm{~m})$ l'apport d'oxygène par diffusion - comparé avec la consonzmation biologique d'oxygène - reprend une grande importance.

\section{ACKNOWLEDGMENTS}

The author is grateful to Werner Stumm for the opportunity to visit EAWAG. The financial support of EAWAG is acknowledged. The acknowledgment is also due to H. Ambühl and T. Blackburn, and Miss Alician Quinlan for their helpful discussion and critical reviewing of the manuscript.

\section{REFERENCES}

[1] Mortimer, C. H., The Exchange of Dissolved Substances between Mud and Water in Lakes, J. Ecol. $29,280-329 ; 30,147-201$ (1941-2).

[2] Sснмidт, W., Der Massenaustausch in freier Luft und verwandte Erscheinungen, Probleme der kosmischen Physik, Bd. 7, viii, 118 p. (H. Grand, Hamburg 1925).

[3] Zimmermann, P., Chemische und bakteriologische Untersuchungen im unteven Zürichsee während der Jahre 1948-1957, Schweiz. Z. Hydrol. 23, 342-397 (1961).

Address of the author:

Prof. Dr. Yuan-Hui Li, Institute of Oceanography, National Taiwan University, Taipei, Taiwan. 